\section{Core caper}

\author{
Journey to the Center of the Earth \\ Film directed by Eric Brevig \\ In UK and US cinemas now
}

When Jules Verne wrote A Journey to the Centre of the Earth in 1864, science was still coming to terms with the planet's extreme age, and Verne's story of a swiss-cheese globe containing vast seas and prehistoric creatures had a satisfying ring of plausibility. The novel's eccentric scientist, Otto Lidenbrock, invokes real-life researchers from Humphry Davy to Joseph Fourier, and the thrilling plot is regularly punctuated by scientific musings that were then cutting-edge.

The book may have inspired many to become geologists, but for recent generations of readers, the obvious impossibility of the subterranean voyage has detracted from its allure. It was even "too fantastic" for David Stevenson of the California Institute of Technology, Pasadena, who proposed an unmanned mission to probe Earth's core in this journal in 2003.

So this 2008 cinematic visit to Verne's strange subterranean world is more akin to fantasy than science fiction. Journey to the Center of the Earth, the new 3D film by special-effects guru Eric Brevig, is silly — in a good way. And within its imaginary world, the film holds science and fact in high regard.

The film is not an exact remake of the novel. Rather, it imagines a world where a few presentday maverick geologists called Vernites believe the novel to be fact not fiction. The action follows a geologist, played for broad comedy by Brendan Fraser, his sullen teenage nephew

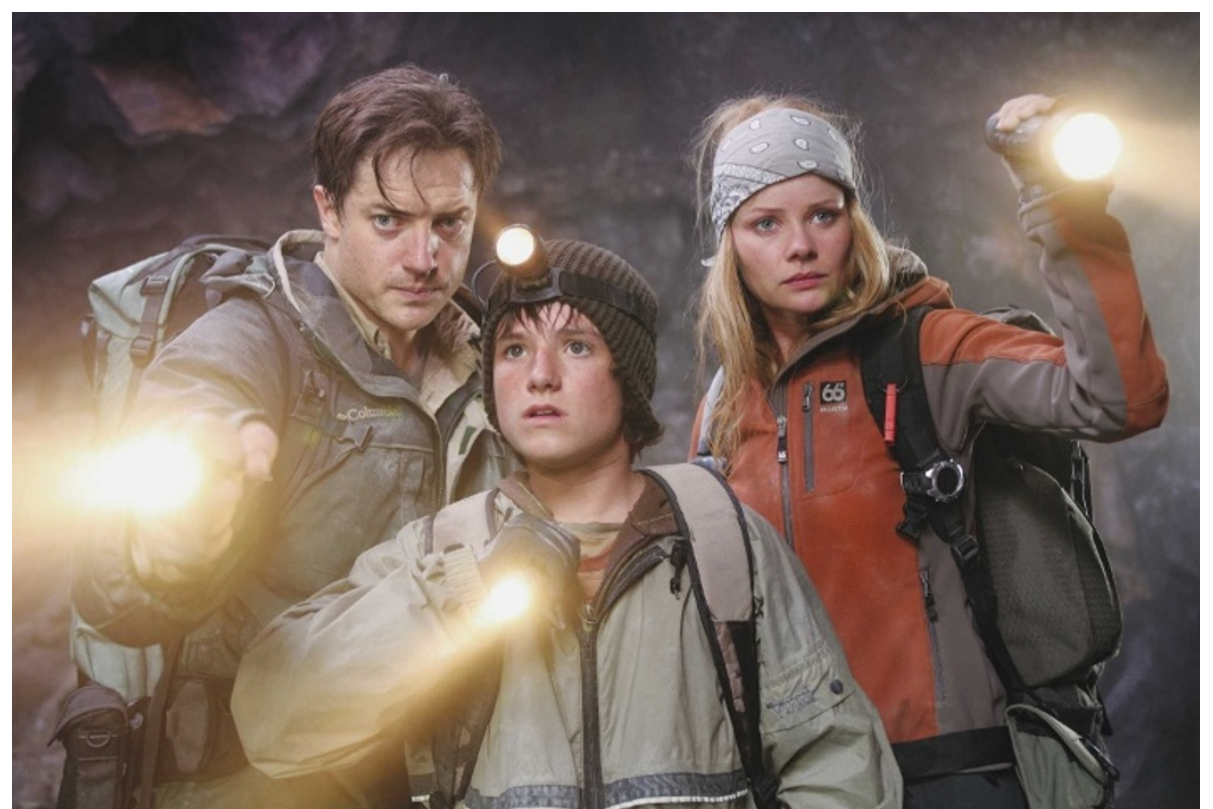

Jules Verne dismantled: Journey to the Center of the Earth is silly, but holds science in high regard.

(Josh Hutcherson) and the Icelandic daughter of a missing Vernite (Anita Briem).

A sleight of hand with the science - a few "seismic readings" on a computer screen gets the trio to the centre of Earth. But once underground, science saves the day as Fraser's character shows expert knowledge of mineral properties that rescues them from lava, dinosaurs and the like.

The film's tough scientist hero and its exciting caverns and formations might even have the effect on young audiences that the novel presumably had on previous proto-geologists. It vividly portrays the geological world of rocks and lava as diverse, dynamic and cool. It also pokes fun at the maverick scientist trope, with deadpan lines like "Although [he] was ridiculed by the scientific community, he was eventually found to be correct."

That said, the movie is pretty mindless. It has the standard comedic patter in the face of danger, with punchlines you can see coming all 6,400 kilometres from the centre of Earth. Mandatory shots take advantage of the $3 \mathrm{D}$ to make the audience jump. Happily, it doesn't take itself too seriously: "Eat your trilobite son; you've got to keep your strength up." And its new and improved 3D effects are a lot of fun to watch.

Emma Marris is a correspondent for Nature.

\title{
Geological history turned upside down
}

\author{
Worlds Before Adam: The Reconstruction of \\ Geohistory in the Age of Reform \\ by Martin J. S. Rudwick \\ University of Chicago Press: 2008. 614 pp. \\ $\$ 49.00$
}

Geologists study Earth by applying principles borrowed from more fundamental sciences. Yet geology also has its own set of attitudes that have accrued during the discipline's long history. The nature of geological inquiry, involving a synthesis of historical and philosophical reasoning, lies at the heart of Martin Rudwick's fine new book.

Worlds Before Adam shows that the emergence of modern geology was comparable in its cultural impact with that of relativity or Darwinian evolution. Rudwick, an influential historian of Earth science, emphasizes geology's historical and causal approaches to understanding, complementing his magisterial book Bursting the Limits of Time (University of Chicago Press, 2005). This earlier work covered the period between 1787 and 1822, when French savant Georges Cuvier and his fellow continental geologists gave meaning to signs of the past, such as fossils and strata, in the same way as historians and archaeologists use monuments and archives to map human history. Worlds Before Adam looks at how the ideas generated by Cuvier and others came together with more theoretical concepts between 1820 and 1845 .
Rudwick's books are myth-busters, of which writers of introductory geology texts and popularizations should take note. In both volumes he counters the Anglocentric view that James Hutton, William Smith and Charles Lyell were the founders of modern geology who shone their British intellectual light onto the darkness of continental musings. To a large degree, he argues, the reverse was the case.

Controversially, Rudwick challenges the view that geology's development is a story of secular progress. He shows that the founders of geology were almost all men of faith. Yet they often engaged in fierce debates with pseudo-scientists who ascribed absolute authority to readings of the Bible. Theologians have discredited such 